\title{
Residents' Well-being of a Village in a Great City. Case Study: Kampong Bharu (New Village), Kuala Lumpur City
}

\author{
Oliver Ling Hoon Leh, Hazirah Azami, Marlyana Azyyati Marzukhi, Kwong Qi Jie \\ Faculty of Architecture, Planning and Surveying, Environmental and Social Health Research Group, \\ Universiti Teknologi MARA, 42300 Puncak Alam, Selangor, Malaysia
}

oliverling.my@gmail.com, hazirahazami1@gmail.com,marlyana@uitm.edu.my, kwong@uitm.edu.my.

Tel: $+6012-2380503$

\begin{abstract}
Urbanisation, a human settlement is growing from a village to a megacity. However, there are few cases of villages, which had been lacking behind in the trend of urbanisation. For instance, Kampong Bharu (New Village) had been maintained as a village setting even though it is located within the boundary of Kuala Lumpur city. A study has been carryout to examine the residents' well-being of the Kampong Bharu by using a questionnaire survey and statistical analysis. In general, the well-being of villages was within a moderate level. The social and economic developments were contributed to the psychological well-being of residents.
\end{abstract}

Keywords: City; correlation; quality of life; satisfaction

eISSN: 2398-4287 @ 2020. The Authors. Published for AMER ABRA cE-Bs by e-International Publishing House, Ltd., UK. This is an open access article under the CC BYNC-ND license (http://creativecommons.org/licenses/by-nc-nd/4.0/). Peer-review under responsibility of AMER (Association of Malaysian Environment-Behaviour Researchers), ABRA (Association of Behavioural Researchers on Asians) and cE-Bs (Centre for Environment-Behaviour Studies), Faculty of Architecture, Planning \& Surveying, Universiti Teknologi MARA, Malaysia. DOI: https://doi.org/10.21834/ebpj.v5iSI2.2523.

\subsection{Introduction}

Malaysia, a developing country, was facing a high rate of urbanisation. The proportion of the urban population increased to $71.0 \%$ in 2010 , compared with $62.0 \%$ in 2000 (Department of Statistic, 2011). For Kuala Lumpur, there is $100 \%$ urbanised (ibid). Globally, population growth is more concentrated in urban areas. In 2000, almost half of the world population (46.6\%) lived in urban areas, which was 2.85 billion. The urban population was projected to increase to 4.97 billion by 2030 , which is $59.7 \%$ of the world's population (UN, 2008). Due to the process of urbanisation, cities are under pressure for development due to the high concentrations of population in urban areas (Siti Nur Afiqah et al., 2015). Thus, residents of Kampong Bharu, a village in the city of Kuala Lumpur was also facing the development pressure from the urbanisation process. They were also suffering from the high cost of living, a higher price of housing, traffic congestion and other urban problems.

Based on the theories in town and country planning, development areas can be divided into urban, rural (or village) and suburban. Supposedly, there is a clear boundary between the urban area and the village. However, due to the organic growth of a human settlement from a small village to a megacity, there are few cases of villages, which had been lacking behind in the trend of urbanisation. For instance, Kampong Bharu (New Village) of Kuala Lumpur city had been maintained as a village setting even though it is located within the boundary of Kuala Lumpur city. Nowadays, Kampong Bharu had been surrounded by high-rise city developments. The villages of Kampong Bharu with low-density village settings might suffer from urban living pressure even though they are staying in a village in the city. Thus, it becomes the purpose of the study to examine the residents' well-being of the village in the great city of Kuala Lumpur.

eISSN: 2398-4287 @ 2020. The Authors. Published for AMER ABRA cE-Bs by e-International Publishing House, Ltd., UK. This is an open access article under the CC BYNC-ND license (http://creativecommons.org/licenses/by-nc-nd/4.0/). Peer-review under responsibility of AMER (Association of Malaysian Environment-Behaviour Researchers), ABRA (Association of Behavioural Researchers on Asians) and cE-Bs (Centre for Environment-Behaviour Studies), Faculty of Architecture, Planning \& Surveying, Universiti Teknologi MARA, Malaysia.

DOI: https://doi.org/10.21834/ebpj.v5iSI2.2523. 
The existence of a village within a city boundary can create problems. It is due to the lower housing cost in the village. As a result, the "urban village" will be the place for the low-income group or migrant workers. It also usually characterised by high building density, poor building quality, irregular streets and poor waste management. Research in China (Lin, Meulder and Wang, 2011) showed that a village in the city of Guangzhou was having problems related to urban well-being. This half-urbanised village in Guangzhou, China, was facing problems like slums, hotbeds for crime, social conflicts and inexpensive shelter for migrant workers. The existence of the "urban village" was having an implication on the poor landscape, poor living environment, and high crime rate and safety problems (Lin, Meulder and Wang, 2011).

For the topic of well-being, it consists of psychological, physical, social, spiritual, emotion, health and other elements. An individual will be high in psychological well-being if he or she is experiencing a higher degree of positive effect in life as compared to negative effect. Meanwhile, someone who is low in well-being is suffering from a higher degree of negative effect over the positive effect of life (Bradburn, 1969). Psychological well-being is usually conceptualised as a combination of positive affective states such as happiness and functions with optimal effectiveness in individual and social life (Deci and Ryan, 2001). As summarized by Huppert (2009), psychological well-being is about lives going well. High psychological well-being is related to feeling happy, capable, well supported, satisfied with life, and others.

Well-being can be seen as a set point of balance between an individual's resource pool and the challenges faced by them (Fig. 1). If someone can overcome life challenges with adequate resources, the state of well-being is achievable.

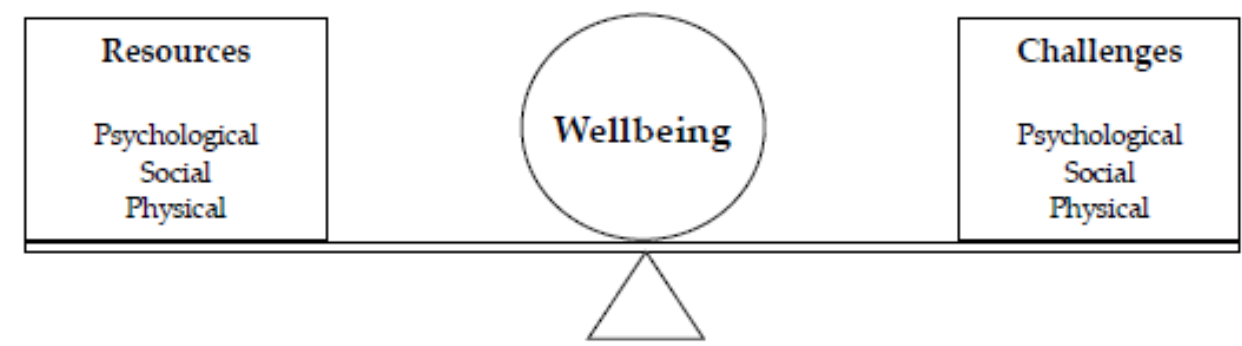

Fig. 1: Balance point of well-being

(Source: Institute for Teaching, 2018)

\subsection{Material and Method}

This study was carried out by using the method of the case study. By using a study area as a case, the study was carried out to cover the well-being of the residents of Kampong Bharu and the relationship among the different aspects of well-being. In total, there are five aspects of well-being, namely psychological, social, physical, economy and environmental quality. Indicators used for the five aspects of well-being, as shown in Table 1.

Table 1. Indicators for the five aspects of well-being

\begin{tabular}{lcl}
\hline Aspects of well-being & Indicators & \\
\hline Psychological & 1. & Quality of life \\
& 2. & Spend time \& enjoy with family \\
Social & 3. & Happiness \\
& 1. & Participation in community activities \\
Physical & 2. & Relationship among neighbours \\
& 3. & Being part of the community \\
& 1. & Satisfaction with facilities \\
Economy & 2. & Satisfaction on housing quality \\
& 3. & Satisfaction with traffic condition \\
& 4. & Satisfaction on the safety aspect \\
Environmental & 1. & Satisfaction on income level \\
& 2. & Satisfaction on the cost of living \\
& 3. & Satisfaction on housing price \\
& 1. & Satisfaction on environmental quality \\
& 2. & Satisfaction on waste management \\
\hline
\end{tabular}

\subsection{Case Study}

Kampong Bharu (New Village) is located within the boundary of Kuala Lumpur city. It is administrated by Kuala Lumpur City Hall. Kampong Bharu was an agricultural settlement established under section 6 of the Land Enactment 1897. Being a Malay Agricultural Settlement (MAS), the history of Kampong Bharu begins in the early 1900s. The village was developed with a special condition that only the Malays could own the land and reside in the area. There are 1,354 units of houses in the village. With the high development pressure from the Kuala Lumpur city, some of the buildings in the village had been redeveloped with modern design. In general, the village is highly accessible to other parts of Kuala Lumpur city via Tuanku Abdul Rahman road, Raja Muda Abdul Aziz road, Tun Razak road and Ampang road (Fig. 2). 


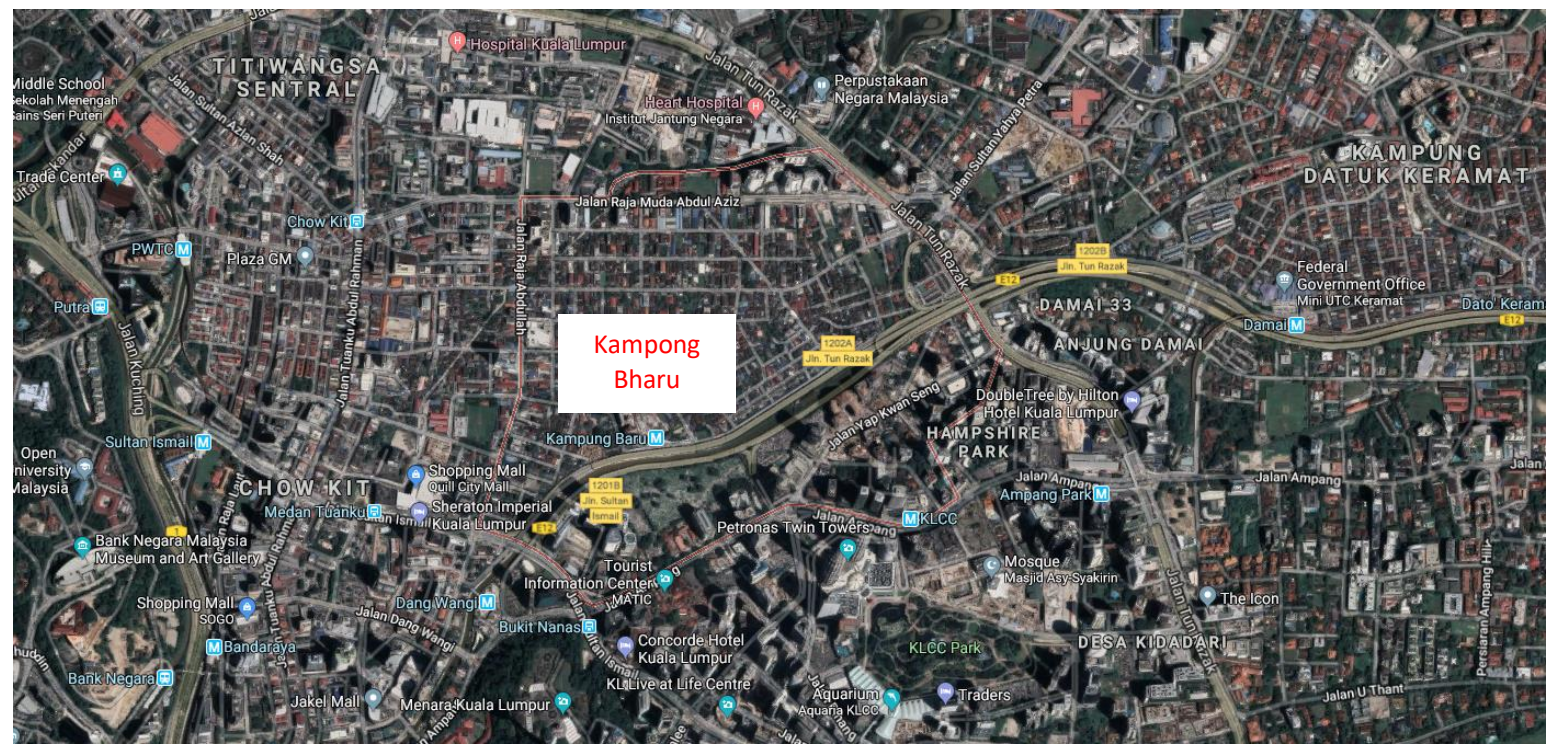

Fig. 2: Location of the study area (Kampong Bharu)

(Source: Google, 2018)

\subsection{Questionnaire Survey and Sampling of Respondents}

The well-being of residents of Kampong Bharu was examined by using a questionnaire survey. A total of 100 respondents were selected randomly from the 1,354 units of houses in the study area. The samples covered both male and female and different age groups. However, all the respondents were Malays. Table 2 shows the general background of respondents in this study.

\begin{tabular}{lc}
\multicolumn{2}{c}{ Table 2. Background of respondents } \\
\hline Variables & Percentage (\%) \\
\hline Gender & 30 \\
Male & 70 \\
Female & \\
Employment & 45 \\
Employed & 31 \\
Students & 14 \\
Housewife & 10 \\
Retired & \\
Age & 30 \\
15-24 years old & 20 \\
25-34 years old & 19 \\
35-44 years old & 15 \\
45-54 years old & 16 \\
$55-64$ years old & \\
\hline
\end{tabular}

\subsection{Method of Analysis}

The data were analysed using the Frequency, Cross-tabulation, and Correlation tests in the Statistical Package for Social Science (SPSS) software. The purpose of the analysis is to find out the well-being condition of respondents and the relationship of physical, social, economic and environmental aspects towards the psychological well-being of respondents.

\subsection{Result and Discussion}

\subsection{The psychological aspect of well-being}

The psychological aspect of well-being was aimed to identify the status of well-being based on respondents' personal feeling and perception of their quality of life, the state of happiness and their life with family. Quality of life is a term used to describe many aspects of life, and it is related to the human perception of ability to meet their needs and well-being (Ling, et al, 2018). Meanwhile, happiness is a state of mind, and it is often related to an emotional state of well-being characterised by feelings ranging from contentment to intense joy (Ling, et al, 2015).

Table 3 showed that most of the respondents felt that they were moderately satisfied with their quality of life and state of happiness. However, the majority of respondents felt that they were unsatisfied with their time spent (and enjoy) with family. Most of the respondents were having part-time jobs besides their fulltime occupations. It is due to the high living cost in Kuala Lumpur. It showed that most of the respondents were not at the satisfied state with their psychological aspect of well-being while living in a village located within the boundary of a great city (Kuala Lumpur). 
Table 3. The psychological aspect of well-being

\begin{tabular}{|l|c|c|c|c|}
\hline \multirow{2}{*}{ Indicators } & \multicolumn{3}{|c|}{ \% of respondents } & \multirow{2}{*}{ Total (\%) } \\
\cline { 2 - 5 } & Unsatisfied & Moderate & Satisfied & 100 \\
\hline Quality of life & 17 & 69 & 14 & 100 \\
Spend time \& enjoy with family & 40 & 32 & 28 & 100 \\
Happiness & 15 & 47 & 38 & \\
\hline
\end{tabular}

\subsection{The physical aspect of well-being}

The satisfaction of respondents on the physical aspect of their settlement contributes towards their psychological well-being. Thus, the satisfaction of respondents on the facilities, housing quality, traffic condition and safety aspect of the study area were examined (Table 4). The study found that most of the respondents were moderately or unsatisfied with the indicators for the physical aspect of well-being. The housing quality and traffic condition in the study area can be considered at a lower level as compared to the facilities and safety aspects. Study area and Kuala Lumpur city were providing good facilities and reasonable safety condition to the respondents. However, the traffic condition was poor. As part of Kuala Lumpur city, the study area always suffered from the problems of heavy traffic volume and traffic congestion. Besides, the housing quality was low in the study area. Most of the respondents were not satisfied with the quality of village houses in the city of Kuala Lumpur.

Table 4. The physical aspect of well-being

\begin{tabular}{|l|l|l|l|l|}
\hline \multirow{2}{*}{ Indicator } & $\%$ of respondents & Total (\%) \\
\cline { 2 - 4 } & Unsatisfied & Moderate & Satisfied & \\
\hline Facilities & 15 & 50 & 35 & 100 \\
Safety aspect & 35 & 50 & 15 & 100 \\
Housing quality & 39 & 36 & 25 & 100 \\
Traffic condition & 65 & 35 & 0 & 100 \\
\hline
\end{tabular}
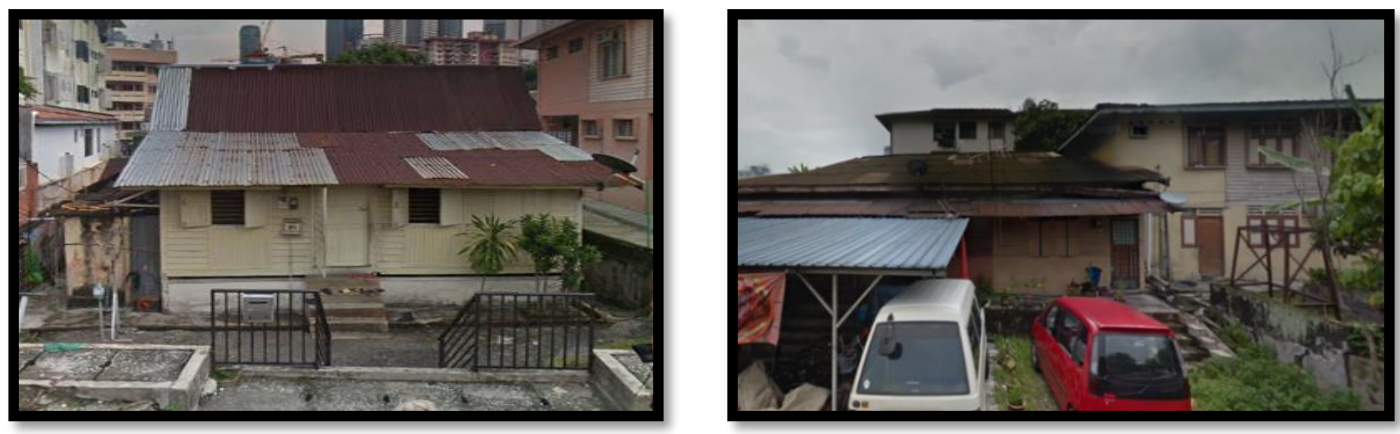

Fig. 3: Example of houses in the study area.

\subsection{The economic aspect of well-being}

Economic indicators, i.e. income level, cost of living and housing price were associated with the well-being of residents. The economic aspect was always used as part of the indicators for quality of life as well as well-being globally. Based on the study (Table 5), most of the respondents were unsatisfied with the cost of living and housing price in the study area. However, most of the respondents were moderately satisfied with their income level. Being part of Kuala Lumpur city (the capital of Malaysia), the level of living cost and housing price was always high as compared to other areas in Malaysia. Simultaneously, the income was also higher in Kuala Lumpur city as compared to other towns or settlements.

Table 5. The economic aspect of well-being

\begin{tabular}{|l|r|r|r|r|}
\hline \multirow{2}{*}{ Indicator } & \multicolumn{3}{|c|}{ \% of respondents } & Total (\%) \\
\cline { 2 - 4 } & Unsatisfied & Moderate & Satisfied & 100 \\
\hline Income level & 37 & 49 & 14 & 100 \\
Cost of living & 50 & 40 & 10 & 100 \\
Housing price & 65 & 35 & 0 & \\
\hline
\end{tabular}

\subsection{The environmental aspect of well-being}

Environmental quality and waste management in the study area were moderately satisfied by the majority of respondents (Table 6). There was only a small percentage of respondents unsatisfied with the environmental aspect ( $8 \%$ to $12 \%)$.

Table 6. The environmental aspect of well-being

\begin{tabular}{|l|c|c|c|c|}
\hline \multirow{2}{*}{ Indicator } & \multicolumn{3}{|c|}{ \% of respondents } & \multirow{2}{*}{ Total (\%) } \\
\cline { 2 - 4 } & Unsatisfied & Moderate & Satisfied & \\
\hline Environmental quality & 12 & 48 & 40 & 100 \\
Waste management & 8 & 77 & 15 & 100 \\
\hline
\end{tabular}




\subsection{The social aspect of well-being}

The social aspect was the only aspect of all the aspects of well-being that satisfied by most of the respondents (Table 7). Most of the respondents (55-65\%) were satisfied with their relationship with neighbours, and they felt that they were part of the community. However, the majority $(45 \%)$ of respondents were only moderately satisfied with their participation level in community activities. Meanwhile, there were $20 \%$ of respondents unsatisfied with their participation level with community activities and relationship with other neighbours. It showed that residents in the village generally more participate in community life and have a better relationship with others.

Table 7. The social aspect of well-being

\begin{tabular}{|l|r|c|c|c|}
\hline \multirow{2}{*}{ Indicator } & \multicolumn{3}{|c|}{ \% of respondents } & \multirow{2}{*}{ Total (\%) } \\
\cline { 2 - 5 } & Unsatisfied & Moderate & Satisfied & \\
\hline Participation in community activities & 20 & 45 & 35 & 100 \\
Relationship among neighbours & 20 & 25 & 55 & 100 \\
Being part of the community & 0 & 35 & 65 & 100 \\
\hline
\end{tabular}

\subsection{The relationship between the five (5) aspects of well-being}

Among the five (5) aspects of well-being, four (4) of them were showing moderately satisfied or unsatisfied by most of the respondents. It showed that most of the respondents were not exactly satisfied with their psychological, physical, economic and environmental aspects of well-being. There was the social aspect alone, showing that most of the respondents were satisfied or moderately satisfied with the social aspect of well-being.

Correlation tests were carried out to examine the relationship between one of the indicators of psychological well-being (which is Quality of Life), and all the indicators from physical, economic, social and environmental aspects. Analysis (Table 8) showed that there were only four (4) indicators having a significant relationship with the Quality of Life. It showed that aspects of physical and environment did not show a significant relationship with the quality of life. All the economic indicators (income, cost of living and housing price) and one of the social indicators (which was participation in community activities) were positively, and significantly (at 0.01 level) related to the quality of life level. For the respondents of Kampong Bharu, the increase of economic and social satisfaction might increase the quality of life level. It shows that people's quality of life was mostly affected by their economic condition while living in a city (Kuala Lumpur) as compared to other aspects such as physical and environmental quality.

Table 8. Correlation tests between Quality of Life and other indicators

\begin{tabular}{|l|l|l|}
\hline \multirow{2}{*}{ Economic: income level } & Correlation Coefficient & $0.358^{* *}$ \\
\cline { 2 - 3 } & Sig. (2-tailed) & 0.000 \\
\hline \multirow{2}{*}{ Economic: cost of living } & Correlation Coefficient & $0.352^{* *}$ \\
\cline { 2 - 3 } & Sig. (2-tailed) & 0.000 \\
\hline \multirow{2}{*}{ Economic: housing price } & Correlation Coefficient & $0.303^{* *}$ \\
\cline { 2 - 3 } & Sig. (2-tailed) & 0.002 \\
\hline \multirow{2}{*}{ Social: participation in community activities } & Correlation Coefficient & $0.439^{* *}$ \\
& Sig. (2-tailed) & 0.000 \\
\cline { 2 - 3 }
\end{tabular}

Note: ${ }^{* *}$. Correlation is significant at the 0.01 level (2-tailed).

$$
N=100
$$

\subsection{Conclusion}

To conclude, this study found that most of the respondents in Kampong Bharu, a village in Kuala Lumpur city were moderately satisfied or unsatisfied with their level of well-being. Among the five (5) aspects of well-being, there was the social aspect of well-being alone, showing satisfied by most of the respondents. It showed that residents in the study area (a village in Kuala Lumpur city) were not in the good state of well-being for the aspects of psychological, physical, economic and environmental quality. Based on the correlation tests, it is found that economic and social aspects were significantly related to the quality of life level. Thus, it is suggested that the economic and social condition of residents should be increased further to improve the quality of life level among residents of Kampong Bharu. The possible development strategy of town planners and government who are more focusing on the physical development of a settlement without seriously looking into the actual benefits to the community should be avoided. According to Hashim and Shuib (2012), although there were concerns for ensuring the quality of life for the community, it is a common tendency for authorities to focus more on the physical aspects of development and economic growth without comparable agenda in the social aspects.

\section{Acknowledgement}

The authors gratefully acknowledge the assistance of Universiti Teknologi MARA (UiTM) in providing the REI research grant (600RMI/DANA 5/3/REI (8/2015)) for making this study and publication successful. The authors are also thankful to all the departments, organisations, and individual who had contributed to this study. 
Ling, O.H.L., et.al., GTSD2018ShahAlam, Best Western Hotel i-City Shah Alam, Malaysia, 24 Oct 2018, E-BPJ 5(SI2), Dec 2020 (pp.69-74)

\section{References}

Bradburn, N. (1969). The structure of psychological well-being. Chicago: Aldine.

Deci, E. L., \& Ryan, R. M. (2008). Hedonia, eudaimonia, and well-being: An introduction. Journal of Happiness Studies 9: 1-11.

Department of Statistics Malaysia (DOS). (2011). Population Distribution and Basic Demographic Characteristic Report 2010. DOS Official Portal (www.dosm.gov.my) Google (2018). Google maps.

Hashim, H. and Shuib, K. B. (2012). Comparing economic and social indicators towards sustainable development in Selangor, Malaysia. OIDA International Journal of Sustainable Development 03 (12): 39-48.

Huppert, F. A. (2009). Psychological well-being: Evidence regarding its causes and consequences. Applied Psychology: Health and Well-Being 1: 137-164

Institute for Teaching (2018). Well-being - what do we actually mean by it? Retrieved from https://ift.education/wellbeing-everybodys-talking-actually-mean/. $(20$ July 2018)

Lin, Y., Meulder, B. and Wang, S. (2011) Understanding the 'village in the city' in Guangzhou: Economic integration and development issue and their implications for the urban migrant. Urban Studies 48 (16): 3583-3598.

Ling, O.H.L., Farah Ayuni, M., Siti Nur Afiqah, M.M, Yusfida Ayu, A., Marlyana Azyyati, M. (2015). The relationship of human happiness and neighbourhood planning: Case study Puchong Indah housing estate, Selangor, Malaysia. Planning Malaysia Journal 13: 51-64.

Ling, O.H.L., Norseha, M.M., Nur Asma, A.H., Marlyana Azyyati, M., Jamalunlaili, A. (2018). Quality of life among residents in a sub-urban area. Case study: Puncak Alam, Selangor, Malaysia. IOP Conf. Series: Earth and Environmental Science 117: 012028.

Siti Nur Afiqah, M.M., Ling, O.H.L., Dasimah, O., Subramaniam, K. (2015). Theoretical Review on Environmental Health in Relation to Neighbourhood Planning and Human Physical Activity. Procedia -Social and Behavioral Studies: Asian Conference on Environment-Behaviour Studies 201: 325-332.

UN - Department of Economic \& Social Affairs, Population Division (2008). World Urbanisation Prospects: the 2007 revision population database. Retrieved from http://esa.un.org/unup. 